\title{
ETHNIC AND CULTURAL ASPECTS IN THE DEVELOPMENT OF KAZAKH THEATRES DURING THE INDEPENDENCE PERIOD: THE PROBLEMS OF HUMAN EXISTENCE
}

\author{
Askhat Mayemirov, Kabyl Khalykov, Bakhyt Nurpeis
}

\begin{abstract}
The article gives a detailed description of folklore motifs that became examples for performances in the Kazakh theatre. The interrelation of myth and reality, used as the nature of time, is represented by an existential communicational human existence in the ethno-cultural discourse. Here the conditions of existence for the heroes of both the reality and myth are the same. The comparison of the heroes' lifestyle with Kazakh folklore gives a new interpretation quality to the director's conception and dramaturgy. The heroes' destinies under the totalitarian era of Stalin, Khrushchev, and Brezhnev are imbued with personification of folklore myths and legends. The examples given in the study are related to the cultural-philosophical paradigms of modernity and the values of current ethno-cultural transformations. Thus, the inclusion of folklore into the theatre becomes an influential art trend, in which art seeks to give a comprehensive and vivid real-life picture of a person who fights for his/her own destiny and justice. The Gabit Musrepov Kazakh Academic Theatre for Children and Youth solves these problems, using the comparative method of folk stories, encouraging the viewer to understand and appreciate the philosophical meaning of human life and existence. The study uses the ratio of diachronic and synchronic presentation of texts and artefacts as regards current events from the perspective of folklore studies, theatre studies, and art history, as well as from the cultural-philosophical viewpoint.
\end{abstract}

Keywords: acting, dramaturgy, folklore, folk wisdom, performance, philosophical sense

\section{THE VALUABLE MEANING OF THE CULTURAL- PHILOSOPHICAL PARADIGM OF MODERN ART}

Art offers an ideal opportunity to explore the constantly mutually forming human-world system in the form of a regulated model that really exists. Art is a mirror in which a person sees him/herself as reflected in the environment, to say more exactly, sees his/her image in the worldview. The authors suggest understanding the worldview in the most general terms, as an orderly knowledge 
of the reality formed in the public (as well as group or individual) consciousness. Both the image and the picture in the model can randomly change themselves, accepting any forms accessible for imagination. The man-made mirror reflects not only conscious efforts of the creator, but also people's intents, emotional state, and undeveloped properties, and their environment concealed from them. Through the spectator, who perceives a work of art, a feedback is 'locked' in a sense, which allows for classifying and evaluating both the effectiveness of the expressive methods and the peculiarities. It is impossible to find another area of human activity, in which the objective and subjective, reality and fantasy, natural and artificial, conscious and unconscious, mind and senses could be combined to such extent.

The years of independence and sovereignty of the Republic of Kazakhstan have undoubtedly been marked by successes in all spheres, including folklore and theatre. A closer look at the past with a view to learn lessons for the future is a specific feature of the social sciences of today. Therefore, there is a permanent interest in folk culture. The present time is, on the one hand, characterised by urbanisation motifs, and on the other - by the idea of continuity through a new vision of images and means of folklore expression, as well as ways of its rethinking in the context of new aesthetic views.

The specific role of folklore and music in the life of the Kazakhs is reflected in many ancient myths and legends, which confirms the deep historical roots of this cultural layer. Quite a few pieces of art could be compared with the depth and beauty of these myths and legends in Kazakh folklore. They were created by ancient tribes and peoples who promoted the ethnogeny of the Kazakhs, who, in turn, developed rich cultural traditions of their ancestors. Attempts to develop these myths, folklore legends, and deep philosophical understanding of the people often became food for thought as regards Kazakh stage directors, writers, playwrights, and artists. Creative intellectuals, despite certain conflicts arising between the classical tradition and innovation, perceive the deep transformation of art. This results in a completely new dimension of human existence. In this regard, Martin Heidegger properly comments: "Art is put forward in the aesthetics horizon. This means that the literary work becomes the subject of emotional experience, and, accordingly, art is considered to be the expression of human life" (Heidegger 1997: 438). The status of art presupposes non-classical structure of the literary world and equal co-existence and communication of different cultural worlds, linked to the life activity of similarly different, particularly dynamic changeable human beings, who organise themselves according to political, management-economic, ethnic, religious-ethnic, and value-based principles. 
The communicative principle of the literary (cultural) world structuring, which by the end of the century became predominant, changes the way and form of art existence, which becomes a largely significant formation (discourse), bearing (transmitting, communicating) valuable meanings. (Khalykov \& Begalinova 2013: 136)

\section{CREATIVE CONCEPTS OF THE KAZAKH THEATRE DURING THE YEARS OF INDEPENDENCE (1991-2015)}

Kazakh folklore, deeply rooted in antiquity and ethnic history, is represented by heroic tales, lyrical and epic poems, tales, and legends, created mainly on the basis of historical events witnessed by people. Their primary sources could be short stories about the heroism of people, distinguished by military prowess, stories about the tragic love of unhappy young people who challenged injustice, active and proactive people's imagination that revealed itself in the struggle against natural forces. They are deeply patriotic by content, poetic in presentation, imbued with a call for unity, fortitude, perseverance, and tenacity in pursuit of the goal. These stories like a drop of water reflect the fate of these people, their wisdom, and attitude toward the world. Kazakh folklore is unique; it includes more than forty genre varieties, many of which are typical only for Kazakh folklore. This folklore is inexhaustible: it includes not only heroic legends, lyrical and epic poems, stories, legends, folk songs, love and ritual songs, philosophical reflections, dedications, and instructive tales, but also many witty sayings, riddles, aphorisms, proverbs, farewell and funeral chants, lullabies, incantations, and spells, giving a complete picture of the Kazakhs' existence and world outlook.

For many foreign countries, our literature and art are among the main sources of information about the past and present life of the Kazakh people. The intelligentsia of the Asian and African colonial countries, keeping in mind our example, is starting to realise that cultural development depends on political and social freedom, which opens up opportunities for the spiritual growth of the people. (Satpaeva 2015)

The Gabit Musrepov Kazakh Academic Theatre for Children and Youth, more commonly known as the Theatre for the Young Spectator (TYS), has greatly contributed to the development and formation of literary and spiritual culture of our country, the aesthetic taste and world outlook of the young generation, and played a certain role in the development of Kazakh theatrical art. 
Under new historical conditions of the twenty-first century, given the globalisation of all life realities, sharp transition from one social formation to another, and social stratification into rich and poor, the problems of the preservation of the Kazakh nation as an ethnic group complete its mentality, language, and also physical nature. The generally Turkic achievements have become a significant spiritual basis in search of prospects: big worldwide archaeological excavations near Aktobe, in Altai, the decoding of ancient and medieval texts from China, the Far East, the CIS (the Commonwealth of Independent States - the former Soviet republics) countries, and inscriptions on Kultegin stele (a stone statue of the ancient Turkic period). Moreover, the appearance of works authored by Lev Gumilev, Murat Adji, Chingiz Aitmatov, Mukhtar Shakhanov, Olzhas Suleimenov, and the CIS and West orientalists have contributed to a great extent as well.

One could also mention the studies of several prominent researchers of Kazakh folklore. For example, the study titled From Folklore to the Epic Novel by Sheriazdan Eleukenov is a fundamental research that reveals patterns of origin, formation, and development of the Kazakh novel from its beginnings to the works of contemporary writers, which meet high professional standards of novelistic art. The author has studied a solid amount of materials related to the artistic heritage of the Kazakh novel (Eleukenov 1987).

Also, the studies titled The Folklore of Kazakh People in the Contemporary Art of Pavlodar Region (2008) and The Folkloric-Mythological Heritage of the Kazakh People (2007) by Daniyar Mergaliev discuss one of the most topical and popular themes of today's music studies - folk music and music folklore, the history and culture of the Kazakh folk art.

The monograph of Sanya Kabdieva on the folk traditions in the Kazakh theatre discusses the development of folk traditions in the modern Kazakh theatre and identifies the interaction patterns of folklore and artistic structure. The author has studied the influence of these traditions by specific examples of theatrical practice (Kabdieva 1986: 112).

Rich content and various forms of folklore as well as its new productive development testify to the fact that the ancient poetic culture offers opportunities for taking a closer look at the life of the Kazakh people, to feel kinship with their thoughts and interests. It is the word of art that opens up new horizons of human life and culture.

Modern Kazakh philosophy believes that "[---] the mankind understood the necessity of cultural diversity and importance of keeping the idiosyncrasy of ethnic cultures as a factor of human civilization existence" (Aiupov 2006: 74). All this in general corrects the Turkic views on the past, present, and future. 


\section{TIME TO ESTIMATE:}

\section{IN SEARCH OF UNIVERSAL MORAL VALUES}

Kazakh academic drama theatres, like all the theatres in Kazakhstan and the CIS, are trying to find answers to questions such as how to respond to the negative challenges of time and to preserve the eternal moral values of the mankind, and how to oppose evil in all its forms. The TYS aspires to find and disclose people with high ethical principles and multi-sided personal qualities as well as rich spiritual values, this way indicating the right direction of today's life studies, showing real conflicts, characters, and types of interrelations. In this regard, the theatre approaches contradictory psychological aspects and life collisions. The theatre reveals images of modern business people as well as those who are presently called 'the lost generation'. This is a huge number of people of all ages and different social strata. They feel psychologically wretched due to all the negative consequences of the sharp and quick stratification into rich and poor. This is a widespread problem for all the CIS peoples.

During all these years, the TYS has turned to the works of different authors and used all the genre varieties, experiencing both visible success and, naturally, also certain loss in this process. Changes in stage managers' and actors' generations are taking place continuously.

\section{THEATRE AGAINST TOTALITARIANISM}

The issue of disclosing grave facts of Soviet totalitarianism was among the first TYS creative searches and became a topical one during the period 1932-1960. First, there was the 'test site' theme. A drama by Olzhas Suleimenov and Bakkoja Mukaev, titled Zamanakyr (The End of the World, 1992), revealed a nation-wide tragedy: moral and physical sufferings and ecological catastrophes. Stage director Raimbek Seitmetov used publicistical means to display physical abnormalities, psychological depressions, etc. He also emphasised the scornful attitude of the Soviet power towards people's troubles. This performance appeared after closing down the Semipalatinsk test site. Along with the mass media, the theatre was the first to highlight in full scale the facts of national grief on the first anniversary of the sovereign state. The performance in which Gulzhamal Kazakhbaeva was playing appealed to the moral and social-philosophical heights. During all the years of atomic explosions her hero, Salikha, one after another buried her children, husband, neighbours, and relatives. Having survived several tragedies in succession, she nevertheless remained humane and firm. 
This performance is built up on the contrast of two acts. In the first act, the spectator becomes witness of a wedding and high hope for the happiness of Dastan and Malika. However, the festive atmosphere is spoiled by horrible reality: both the white-bearded aqsaqals (male elders) and youths frequently reach for a bottle of alcohol. The stage director's intention is to emphasise the fact that during those years such a social evil as alcoholism entered into the lives of the Kazakh nation. Officer Toleubaev comes on behalf of the local garrison and passes a command for all to evacuate immediately as tests are going to be conducted. Nevertheless, the agitated crowd is not going to leave the native places. Having survived almost a century-long suffering in their fight against Kalmyks for independence, as well as some other grave events, such as wars, people expect to survive the unknown evil. This is a historical-genetic stereotype of national behaviour. However, the reality of atomic explosions dissolves their determination. In the second act, the heroes and their tragic destinies appear in full: all Malika and Dastan's seven children die after birth, and the eighth child is born without hands and legs. In the end, the audience learns that Malika has gone crazy because of her grief, and Dastan has hanged himself. Salikha's twelve-year-old son suddenly becomes blind. The aul practically dies out. The remaining seven-eight people become incurably ill. In the final scene Salikha is sitting alone against the background of the dead aul in a huge steppe; however, judging by her pose, the spectator can see a sparkle of hope for revival. The TYS shocked the spectator by displaying these fearful phenomena through the images of characters, their expectations, confessions, and calls for help.

This performance contributed to the development of national self-consciousness: the socially active people fostered the appearance and strengthening of the Nevada-Semipalatinsk international antinuclear movement.

\section{THE THEME OF STALIN'S REPRESSIONS}

"Those who go against the tide can't deserve the people's pride," is one of the famous sayings from the folklore of the Kazakh people. The exposure of mass betrayals of people during the years of Stalin's repressions became another innovative theme at the TYS and the Kazakh theatre in general.

In 2004 playwright Akim Tarazi wrote a play titled Indet (The Epidemic) in the tragicomedy genre. Stage director Esmuhan Obaev staged a play in which the protagonist turned traitorous, constantly writing letters of denunciation not only against the aul's inhabitants, but even against his own father, mother, wife, and daughter. Actor Doskhan Zholzhaksynov was extremely skilful in 
exposing the phenomenon of Azbergen's (the protagonist) betrayal in terms of both psychology and satire. He justified himself in his internal monologues, blaming the time. The actor immediately changed himself internally in the images of Lenin, Stalin, and Brezhnev. He used the specific intonation of these characters, as well as gestures and mimic peculiarities typical of them. The actor recited his monologues, looking directly into the audience, suddenly switching over to the realistic manner of his hero's behaviour. These immediate changes were very convincing. The protagonist's religion was the will of Bolsheviks and the party. Stalin called such blind executors of the party's directions swordbearers - people devoid of humaneness, honesty, and decency.

In the play, Azbergen feels himself to be the most reliable screw in the state's repressive machinery. The emphasis is always laid on such key figures, as under any circumstances the authorities could rely namely on them. So, the finale can be perceived symbolically: Azbergen, who is tenderly touching the loops of gallows, is very sad about the former times. He was a blind screw in terrible machinery and did not understand his fault and the sin of betrayal. Azbergen's victims exerted pressure on his psyche in his visions. The ghosts of dead people constantly appeared before him, and the phantoms of his mother and wife angrily blamed him. However, none of the external factors or his visions could change his outlook. With the collapse of the USSR new times began. The only thing left for his former chief was to wait and hope until they were able to return to the old 'deeds' and habits. The author warns the spectator about the danger deriving from such people, calling for watchfulness. All the actors (mother - K. Kazhygalieva, father - S. Rakyshev, wife - G. Kazakhbaeva, daughter - K. Baitleuova) played emotionally and truthfully, exposing different levels of national sufferings.

\section{THE DESTINY OF YOUTH IN MARKET CONDITIONS}

The themes of modern TYS performances are different. They include destiny of the young people, who have lost contact with their roots and traditions and found themselves in the atmosphere of the market economy machinery, rejecting moral and religious foundations, their old parents and new-born children. Soullessness, cruelty along with alcoholism, drug addiction and prostitution have become widespread vices.

During that period the following performances were in the repertoire: Auyldan kelgen aru (The Girl from Aul, 1992) by I. Saparbai, En ademi kelinshek (The Most Beautiful Woman, 1993, staged by S. Balgabaev), Zhetim burysh (Orphan's Corner, 1992, staged by A. Kenzhekov) by S. Murtaza, Myn ishinde 
zhalgyzdar (Lonely among People, 2000) by B. Rimova, Atau-kere (Deathly Bowl, 2003) by O. Bokeev, Alma bagy (Apple Orchard, 2006) by T. Temenov, and others. In the performance The Girl from Aul, the heroine comes to a big city looking for a better life and gets into all kinds of troubles. The play by O. Kenebaev is realistic by nature, descriptions of characters, and conflicts. Modern music, slang, costumes, and other attributes are widely used. Actress Kuljamila Belzhanova creates a truthful image of an aul girl in a big city: with all her naivety, social immaturity, and depression. In the final act she stealthily leaves her child with other people and runs away in desperation - a deed typical of the present time. The TYS demonstrates a new interpretation of the Kazakh girl's image: a forced refusal from the national spiritual values, along with the beginnings of moral degradation.

A play by Raimbek Seitmetov, The Most Beautiful Woman, is just the opposite by nature. The heroine (Gulbarshyn) is a charming, beautiful, and strong woman, who in spite of her negative life experience (her husband is unemployed and a drunkard) remains optimistic and is ready to help others. This woman, whose role is played by L. Kadenova or A. Mambetova, has become one of the favourite characters of the audience. The performance has become a hit and is still in the theatre's repertoire.

The play Lonely among People (stage director B. Atabaev) shows the moral degradation of the youth. Aldan (R. Omarov) and his wife Samal (S. Kabysheva) are unemployed. Aldan's mother Kunzipa (G. Kazakbaeva) shares a room with them. Young people scorn her; they are not interested in the state of her health and her spiritual demands. Having an excellent knowledge of all the traditions and moral values of the Kazakh family, the married couple cynically rejects them: they send the mother into an old people's home. Kunzipa understands the difficult position of her son and daughter-in-law and sympathises with them; so she leaves the house without complaints, heavyheartedly understanding the cruelty of time and society. The theatre shows the process of the loss of human values by the nation.

The greatest social evil - alcoholism - is revealed in the play titled Deathly Bowl (written by O. Bokeev, staged by Mukhamedia Akhmet-Tore). The stage director and leading actor Nurkanat Zhakypbai raises the performance to the heights of physiological and philosophical generalisations. The spectator gets acquainted with him when the protagonist Tagan, a former university teacher and drunkard, is hired as an unskilled worker by his former classmate Eric. The action takes place in a mountainous taiga home (Katonkaragay area in eastern Kazakhstan, not far from Siberia). Tagan's responsibilities include taking care of the cattle, mowing hay, and cleaning the house for a bottle of vodka, food, and a place to live in. N. Zhakypbai realistically demonstrates the 
unattractive appearance and behaviour of his hero. Through Tagan's destiny he traces all the stages of a person's moral and physical degradation: the loss of spiritual values, family, and service career.

Already Tagan's first contact with Eric's mother Nurke becomes an impetus for his spiritual turning point. While drinking tea, the woman tells him in a motherly manner:

Son, you must give up drinking. You must remember that you belong to a good family. Your parents are worthy people. In the time of Stalin's repressions they saved many people, including myself. Son, I will help you myself. I will treat you with herbs. (Nurpeis 2010)

At first Tagan does not pay attention to her words. However, some time later, he begins to follow her advice and accepts her treatment. Then something significant happens: he sees the beauty of Aina, Eric's wife. The hero's life gradually and slowly changes in a positive way. He is less attracted to alcohol, and interest in life and surrounding people awakens in him. Having noticed Tagan's transformations, Eric intentionally makes him return to alcohol. Awakening after a hard drinking bout, Tagan understands his new degradation. He feels pangs of conscience because Nurke's and Aina's care has turned out to be useless and he has not justified their efforts. He is unable to endure such thoughts and feelings, and tries to commit suicide. However, Aina, who happens to be nearby, pulls him out of the loop. Regaining consciousness, Tagan bursts out with emotions and at the end of the monologue he suddenly feels a flow of new energy, and is glad that he is still alive. This scene marks the beginning of Tagan's spiritual healing. The price of his life and death becomes understandable to him and he is happy to be alive, looking forward to his new full-blooded life. This moment becomes a turning point. He gives Aina a bunch of flowers, taken from his bosom. He presents the flowers silently, and she silently accepts them. The spectator understands that they have made a declaration of love. Actor N. Zhakypbai truly and precisely shows all the nuances and emotions in the hero's behaviour. His eyes are incredibly expressive, and there are sometimes confident, sometimes shy gestures, pauses, and the dynamics of acting. The actor reproduces the difficult and delicate process of spiritual renaissance, self-consciousness, dignity, and common sense.

On his way he meets an old hunter, who tells him about his father. The hunter says that his father was an akyn (Kazakh folk poet and singer), and reads one of his verses by heart. Tagan is shocked, and he tries to remember the verse. This meeting gradually changes him and strengthens all his good intentions, awakening in him the love for his motherland, its people, and traditions. The restoration of genetic memory gives a new purpose to his life, creating a desire to find his own self and confirm himself as a member of society. 
Another central character is Nurke, played by R. Ashirbekova, People's Artist of the Republic of Kazakhstan. In many aspects she reminds us of mothers on the Kazakh scenes, and in this aspect she is traditional, with her rich spiritual world, warm-heartedness, and activeness. However, she is also different. In the first minutes, the performance shows a figure of a woman in snow-white clothes, sitting on a white bed and praying, with a rosary in her hands, and it is obvious that she has been hopelessly ill for a long time already. However, she is not depressed. Nurke most actively participates in the destiny of each character and comments on everything that is happening. She appropriately remembers moments from the past life, and permanently evaluates events taking place in the republic, from an average person's perspective.

Being bedridden, the mother turns out to be a positive and energetic engine of the performance: she helps Tagan to change, helps her beloved daughter-inlaw with tender looks and words, encouraging her independence, views, and devotion to traditions. She has a vivid perception of reality and an inner moral reaction to everything that happens. Through her, people express their opinions about alcoholism as a terrible trouble for each family and for the nation as a whole. She represents not only the mother of her son, but also the mother of the Kazakh nation, which desperately fights to preserve kindness and generosity. Nurke is truly religious, yet not a fanatic. The audience understands that her prayers are concerned with not only her personal destiny, but with the destinies of the surrounding people and the whole nation. Actually, Nurke is a Russian woman called Nyura. She has married a Kazakh and given birth to her son Eric, and she has lived in an aul all her life. The meaning of her life is devotion to her family and national traditions. This woman not only learns the Kazakh traditions and customs with full spiritual readiness and desire, but also observes them throughout her life and teaches others. Nurke knows that she cannot call her parents-in-law by name, as this is regarded as disrespect for them, and she has also learnt that it is necessary to give kumis or some other milk drink even to a casual guest after welcoming, as well as to give this guest an honourable place to sit. Also, she constantly remembers that each person must know their family tree up to seven generations and that the Word and Speech have magical meanings: a good word attracts good deeds, and an evil one - evil deeds. She permanently recites fragments from Kazakh epic literature, proverbs, and sayings by heart, and knows the verses of Kazakh poets. Nurke appears as a vivid encyclopaedia of the national worldview and traditions.

The final scene is most comprehensive as regards its content and expressiveness. During the final minutes of her life she drinks several sips of water. (This is the last deathly bowl that in the Kazakh language is called atau-kere, and, as a rule, all people ask for it before death.) Then she reads Koran prayers 
necessary at that moment, and counts rosary beads. Suddenly an unexpected turn follows: Nurke-Nyura recites the formula, "In the name of the Father, and of the Son, and of the Holy Spirit", and reads this Orthodox Christian prayer to the end, and then she crosses herself, lies calmly down, and dies.

This is a big shock both for Aina and for the audience. During the decade they have lived together, she never heard any Russian words from her beloved mother-in-law. So she is deeply surprised. However, already by the end of the prayer, the audience perceives a deep unexplained feeling, which lives in the soul of each person: the belief in one god for all, to whom the humans always turn with prayers in all languages. In her last breath, Nurke-Nyura appeals to Him not only as to a Muslim, but also as to a Christian, as someone with the same beliefs as her parents. Two forms of religion live in concord in her soul, and she makes the audience understand this unity. The theatre here approves of the necessity of religions (as the centre of God) and moral values, which should again become the basis of life.

The modern Kazakh philosophy says:

As regards the continuation of ethnic and cultural self-identification, we can speak about religious identification, proceeding from the assumption of religious diversity as a display of single religiousness. At the same time, this is the normal life of the human community as well. (Aiupov 2006: 101)

Kazakh folklore has kept many traditions emanating from the Tengri beliefs of Turkic peoples. Tengrianism was the prevailing religion before the adoption of Islam, which is marked by the philosopher Nurmagambet Aiupov in the following way:

Tengrianism as a cultural phenomenon, as an open world outlook and as a religious idea is the legacy of our ancestors [---] The disclosure of its manifestations in the consciousness of modern man - the carrier of the ancient Turkic world archetype, allows for making a conscious cultural selection in the variety of modern philosophical ideas. (Aiupov 2012: 5)

Verbal folklore of the Kazakh people, besides other epic forms, has been thoroughly studied by the outstanding Kazakh writer Mukhtar Auezov. He has described the zhoktau from the Kazakh folklore in small and diverse poetic forms. "Every event in the life of Kazakhs - be it birth, death, or marriage - is reflected in a song. Zhoktau is a memorial song, which lists the advantages of the dead person" (Auezov 2012: 3).

Having closed the eyes of the deceased, Aina begins to sing zhoktau, the Kazakh mournful song. This detail once again emphasises the deep idea that morally and spiritually people do not oppose each other as representatives of 
different nations and religions. A. Imanbaeva plays Aina's part authentically, sincerely, and with rich psychological nuances.

The image of another character - old hunter (K. Zhakibai) - is psychologically close to Nurke's image. Although he appears on the stage only twice, in short episodes, he is remembered by the audience as a truly national character, who is a keeper of national memory, spiritual richness, and human tenderness. K. Zhakibai depicts him as a person who remains fair and stable despite all life troubles and who distinctly distinguishes the boundary between good and evil. This is a man of great personal dignity. He helps Tagan in the process of his healing. The old man forms a harmonious spiritual duet with Nurke.

Eric-Nurke's son - is an antipode to all the other characters. He is a strong, well-educated man, who is not satisfied with living merely on salary, without any career prospects. Having left his parents' house, he has built a new one in the mountains and become a social recluse. The main purpose of his life is increasing his wealth. Played by actor K. Kuandykov, Eric is a merciless miser who blazes with fury. He tries to mislead Tagan in order to make him an obedient slave. Beekeeping has made him enormously rich. Eric's insatiability can be blamed on his own mother, which the audience can see in her eyes, the expression of her face, silence, and short annoying remarks.

The stage director N. Zhakypbai uses the method of phantasmagoria. During the whole performance, from time to time the audience can hear the humming of bee swarms either loud nearby or in the distance. Obviously, these are Eric's pets - the basis of his richness. From his remarks the audience learns that his bees are unusual: the local bees are crossbred with the American ones. This new genotype gives more honey, but the bees are very aggressive. The sting of even one of those bees can kill a man. At the end of the performance this happens: one of the bees stings Eric's mother, who dies on the same day.

Bees are Eric's big love. He is enthused when speaking about them, and vividly imitates their movement. At this moment he seems to transform into a bee himself. It is surprising and awful at the same time. Actor K. Kuandykov is psychologically truthful in his monologue and his supple imitation of bee movement has an almost hypnotic impact on the audience. The stage director together with the playwright Oralkhan Bokeev reaches the existential level of thinking: a man who voluntarily rejects moral values reaches the existential level of a fauna species. It is expedient to emphasise here that O. Bokeev wrote his play Deathly Bowl in the mid-1980s. The writer skilfully predicted the spiritual-ethnic collapse, which was interpreted by the TYS in the light of new historical reality. As it turned out, the prophecies made by O. Bokeev came true. Similarly to Zamza's transformation into a cockroach in Kafka's Metamorphosis, the author predicts the destiny of his nation, who feels the colonial oppression, 
war, hunger, genocide, and nuclear tests, and is worried about how the Kazakh nation will be able to keep its mental and physical health and idiosyncrasy.

In the play Deathly Bowl alcohol is considered the poison for the nation, which can destroy the whole ethnic group. The theatre has convincingly implemented this idea with modern underlying themes and details. As a rule, plays devoted to historical themes have been of great importance in the theatre's repertoire. The stage directors and actors subscribe to the spirit of modernity, making spectators their like-minded persons. The historical facts and characters do not remain illustrations of the past; they are filled with a modern spirit. The TYS solves the tasks of cultivating patriotism and responsibility in the youth.

In the play Abaidyn zhastyk shagy (Abai's Youth) (stage director N. Zhakypbai, 1995), the process of Abai's (a Kazakh poet and educator) development as a poet is most substantial. The impulsiveness of his nature, brightness, and power of his internal world, openness and activity of the hero are depicted by $R$. Omarov with great skill. The main innovation of this performance is connected with the original interpretation of Kunanbai's (Abai's father) image. This is a true historical personality. Earlier on, in the performances of the Auezov theatre, Kunanbai was interpreted as a despotic feudal lord and as a negative personality; however, the TYS gives the spectators real facts of his biography and his spiritual world, and shows him as a progressive figure of the nineteenth century, a thinker and a practitioner. The solution of mass scenes, expressing constant unanimity of Kunanbai and Abai with the nation, is very interesting.

The production of Isatai - Makhambet (Isatai - Makhambet, 2003), a play by I. Zhansugurov, staged by Zh. Khadzhiev, demonstrates Isatai's heroism, love to native land and humanity as a batyr (Kazakh hero, warrior) and poet, brother-in-arms of the great Makhambet Otemisuly (the great Kazakh hero, poet, and political figure) in the fight with colonisers in the nineteenth century. Actor T. Meiramov shows with great psychological skill the last hours of Isatai's life. He knows that the armed forces of Zhangir-khan, jointly with the Russian forces, will soon kill him and Makhambet; nevertheless, not wishing to shed the blood of his people, Isatai wants to solve everything in a peaceful way. He believes in the false promise of Zhangir-khan, gets into a trap and dies, defending his land and people. The courage and powerful spirit of the batyr win the spectators' hearts.

The stage production of S. Zhunusov's Turumtaydai ul edy (Falcon's Son, 2004 ) is similar to the former play. Stage director Zh. Khadzhiev reveals the image of the young Abylai-khan in all the components of the play. Teenager Abylai has remarkable character features, such as love for his native land, 
courage, ability to use weapons, and a gift to understand people from different social strata.

It should be specifically noted that the national and classical works remain in the centre of the TYS's activities. A musical drama by G. Musrepov, Kyz Zhibek (Kyz-Zhibek - a Kazakh version of Romeo and Juliet, 1999) - one of the best works of Zh. Khadzhiev, an outstanding stage manager - has been on already for several years. The well-known legend is thoroughly comprehended in deep contextual, psychological, and socio-philosophical aspects. The stage director develops the best achievements of the Kazakh theatre at a high creative level and along with it opens the new artistic structure of the performance in the national classics.

First of all, the performance is filled with deeply personal, philosophical, and psychological understanding of the national heritage to which Kyz-Zhibek belongs. In this regard it should be stressed that the staging methodology is truly innovative, modern, and authentically national. Owing to the creativity of Zhanat Khadzhiev, the Kazakh stage management as a whole was raised on a new level of achievement in classical stage productions. The talented stage director always raises many moral and psychological problems and reveals new problematic issues. In his interpretations, Zh. Khadzhiev effectively uses such categories as time and space, which requires deep understanding of the actors and the spectators. His performances are usually full of powerful psychological and psychophysical energy. All the components of performances are filled with his willpower, which makes visible not only the characters' emotions, but also their secret thoughts and views.

Zh. Khadzhiev always relies on a spiritual-religious basis, national original and philosophical mind-set, and poetic perception of the world. During historicalsocial cataclysms they remained half-forgotten, as if they were levelled. "Due to his powerful creative impetus, the stage director activates this deep knowledge and memory of soul and heart, which come from the depth of time and space, nomad civilization, and live in each spectator" (Nurpeis 2010).

All Zh. Khadzhiev's stage management solutions are always spectacular, informal-extensional, and easily remembered. He is specifically known by using music, painting, pantomime, and metaphors. It should be especially emphasised that he uses metaphors from different sources, such as folklore, natural world, and nomad craft, and also creates new ones. However, using even widely known national metaphors, he puts his emotional, psychological, and philosophical soul in them. Constant creative tension is typical of each of his performances. It is his way of modern historical reality perception and active influence on it. 


\section{KORKYT'S IDEA OF FIGHTING DEATH}

The history of national culture is a process with its own specific features, which are displayed in the events and phenomena, reflecting worldview, world perception, and mental properties of the nation. "The whole Kazakh culture is filled with ideas, images, and symbols, which, to some extent, are connected with the rites, playing, and ethnic groups" (Khalykov \& Karzhaubaeva 2013: 217).

Several stage productions based on the works of Chingiz Aitmatov have been staged at the TYS: Istykkol tragediyasy (Issyk-Kul Tragedy) and Ak keme (White Steamboat) in 2001, by stage director S. Asylkhanuly, Zhan azaby (Soul Sufferings) on the motives of several works by Aitmatov, in 1997 (stage director N. Zhakypbai), and also Korkyttyn kori (Korkyt's Grave) by Iran-Gaip in 2002, which all reveal modern physiological collisions.

The poetic drama by Iran-Gaip, titled Korkyt's Grave (stage director Z. Khadzhiev), has been on at the TYS already during several seasons. In this performance, Korkyt's personality (who, according to folk legends, was a great shaman who fought until death and did not give up) is sacredly meaningful for Turkic peoples and has an interesting dramaturgical and scenic interpretation. The performance does not aim at the reproduction of historical reality of the seventh century; it is rather a reflection of the artistic perception of the present life of people with all the collisions: interpersonal, social, and daily ones, as well as a search for human spiritual values. In this play Korkyt is not displayed as a traditional folk character. The legend about Korkyt, the founding father of Kazakh music, has a deep philosophical content. Korkyt cannot reconcile himself to the inevitability of death and leaves people, going to the eternal nature, but the mountains, steppes, and forests tell him that the destruction has been inevitable. Then Korkyt takes a piece of wood, hollows out a shirgay - the first kobyz (a traditional Kazakh string instrument), and plays the first melody, finding immortality in the art.

Korkyt, impersonated by Baltabay Seitmamytov, is interpreted as a person in a spiritual crisis; he is looking for the meaning of his life and thinking about the significance of death throughout the whole performance. Collisions of his spiritual perceptions of the meanings of life and death are different and deeply significant, supported by all the components of the performance, first of all, by philosophical conflicts, the dispute of Korkyt and Azrail. Korkyt is not willing to die, and (despite his asking for it) his parents, friend, and mistress also refuse to give their lives for him. Only his devoted wife agrees to die instead of him. The ironic Azrail (T. Kuraliev) calmly states that all are mortal because it is the law of life. However, everyone should find their life goal. At the end of the

performance Korkyt also comes to this conclusion. The maturity of his human 
spirit, the victory over himself and his biological essence transform Korkyt into a great sacral figure. B. Seitmamytov shows Korkyt's constant nervous tension. He renders the emotional perturbations in the character's spiritual life and, remaining subdued in all scenes, displays himself as a master of psychological game. Thus, he brings his character closer to the audience.

The spiritual greatness is, first of all, displayed in Korkyt's actions and his influence on the people around him. In search of his creative self and upon the will of the Absolute he becomes a great kobyzist. Bayterek (poplar) is a tree that he hews with an axe to make the instrument which gives incredible cosmic sounds. Having created the instrument, Korkyt immediately begins to play with great perfection and skill. His music subdues everyone, including Azrail, who is charmed by it and forgets about his initial goals.

The closeness to folklore is displayed in the following moment: the kobyz is made of Bayterek; in Turkic consciousness it is the world tree that unites the sky, land, and the underground world (the world of the dead). Thus, the sacral nature of Korkyt's image is revealed. The sacral nature comes from the Absolute and at the same time he comes to it as a result of his search for the meaning of life. The idea behind Korkyt's search lies in the fact that a human being should learn not to be afraid of life difficulties. The forty-year-old man, full of energy, rises above the crowd. He is a human being and at the same time a God's representative, chosen to be a mediator between people and the cosmos.

Exposing the theme of the crowd and personality, the stage director enriches the intention of the playwright. First of all, it is well expressed in plastic arts. In the course of the performance, the crowd is pushing Korkyt out of its environment, either absorbing or alienating him, or seemingly throwing him away. Further on, it is expressed in the existential social-psychological conflict. In some country the ruler has died, and people are in mourning. Korkyt, who has arrived there, is not aware of this. People ask him to revive Khagan (the ruler, impersonated by S. Zhylkeldiev). Korkyt appeals to Azrail with a request to return his soul, and begins to play his incredible music. Being subdued by the music, Azrail returns life to Khagan. He and the crowd even forget to thank Korkyt. The crowd welcomes Khagan and begins to worship him, i.e. the habitual relations between a ruler and common people are displayed. In addition, each of them pursues their concrete goals. The first words of Khagan after awakening to life are: "Where are my crown and my throne?" People begin to give him gifts and pester him. All of them immediately forget about the great cosmic event: Korkyt's belief in the Absolute, his powerful talent, and the great magic force of art, which helped him to get the soul of Khagan from the angel of death.

Thus, the stage director gives the spectator an idea about the behaviour of today's officials and office-seekers, as well as those who are engaged in pursuit 
of richness and different job positions. Their main goal is be on the top in any situations. Here the stage director blames the crowd for being unspiritual and aimless. The behaviour of the crowd reminds us of today's people, rushing to parties, meetings, and other 'soap bubbles' of social activity.

Any shocks (as death in this case) must spiritually and positively change humans, but both Khagan and the crowd still remain common people in the spiritual aspect, devoting themselves to the 'empty' goals just as it was a thousand years ago. The scenography of L. Tobasheva is simple, expressive, and extensional at the same time. In its depths the powerful blue waves of the sea are seen, merged together with the same light-blue sky. The connection between mortal and cosmic is obvious. Here from time to time a flashing light appears. Depending on the situation, this light embodies either the impact of the Absolute, or enlightenment, or the light of human mind, or a good impulse. Based upon this space, the scene area is a piece of land and people's existence here is perceived philosophically. The stage director metaphorically emphasises that people are always walking on the edge (of their graves). As regards Korkyt, it is expressed in the fact that wherever Korkyt goes, the grave is waiting for him.

Black stones on the seashore are another metaphor. From time to time they move, roll down on each other, and some of them emit light from within; sometimes a ray of daylight drops on them. The stones embody the nature, keenly reflecting the heaven's will. However, in certain spiritual-emotional moments of the performance, they appear as the embodiment of separate people, which in urgent situations are 'flamed' spiritually. At the same time the stones can be perceived as heavenly meteorites and as pieces of Caaba. It means that heaven and earth permanently and vividly communicate with each other, and that people should check themselves even in their daily lives, following the laws of moral world development. This is the unity of the cosmos and all the elements of being: people and heaven, steppe with its wildlife and plants, and stones. It seems that everything constantly interacts with the cosmos, either reacting to its signals or being rejected because of sluggishness. Another polysemantic metaphor of the performance is the abundance of big 'rolling stones'. This is not only the steppe reality, but the images of people, who imprudently follow the will of others and their unchangeable calculations. Moreover, the Kazakhs have a proverb saying, "The human head is Allah's ball". In other words, it is the recognition of human predestination. A howling wind is blowing on the stage and the 'rolling stones' are gathered either in one place, or roll in different directions. Depending on the scene's content, they convey a horrible impression of the feeling of spiritual loneliness, and of the understanding of life tragedy, thus causing suffering and pain. 
At the same time, the aggregate of metaphors and their meanings is expressed in Korkyt's spiritual feelings, and causes his desire at least to raise people's optimism, if only for a while, thus reviving connections with moral values that emanate from the Absolute.

The principle of earthly life limits, established by the Absolute, enables people to succeed in the implementation of their own life goals and tasks. The stage director and the scenic designer skilfully and unconventionally express this principle also in Azrail's dress. He wears a dark-red long chapan (men's coat), with a brown kerchief on the head, with crimson tassels, and a brown shirt and black boots. At first sight, it looks like daily clothes of a steppe dweller. However, scarlet wings make Azrail's figure sacral and ominous. They are seen, when he flaps his arms, from the sleeves down along the body. Each time, when the red wings are seen, the image of blood immediately appears, i.e. a thought of death that is always close. The dark colouring of the chapan and shirt intensify the horrible impression. It becomes clear at once that this is a routine appearance of the Angel of Death, who constantly sheds blood when he takes human souls. The fresh and old blood both show in the colouring of his dress. In the believers' perceptions Archangel Azrail sheds blood in the astral world in the very moment of human death. The stage director has made a brave step: he expresses this view in the dress colouring and red wings, which shock the spectator. This is both a psychological and a moral shock, which gives impetus to thinking about life and death.

In the performance only Korkyt can see the Angel of Death. The others cannot even suspect that this angel is quite close. This significant metaphor reveals the philosophical content of the stage production. T. Kuraliev opens the image of Azrail as an ironic person: he knows how miserable his attempts are to avoid death, so he is calm, confident, and internally laughs at the human efforts to avoid death. There is one disputable moment in the performance, connected with the image of Azrail. When the Angel of Death is about to take Korkyt's life, the latter gives him his kobyz. It means that the great sacral instrument that helps people and saves them is passed into the hands of death and taken away from life, i.e. it passes into Nothingness. The playwright has done it intentionally, in spite of the folkloric plot. In the tales about Korkyt, the kobyz is passed to the baksy (shaman), or, in other words, to an especially talented person; thus the kobyz and the relevant spiritual-aesthetic beginning prevail throughout ages. Iran-Gaip gives the kobyz into the hands of death, thus wishing to tell his contemporaries that presently the connection with the sacral world is lost and the world of people has turned out to be on the edge of an abyss.

Korkyt gives away the kobyz because there is no worthy successor close to him. This is an awful and distinct moral-psychological detail. The music of 
A. Raiymkolova is one of the main acting characters in the stage performance. It sounds from the very first minute of the performance up to the last one, changing the characters' mood and taking the spectators from the meditation to the premonition of tragedy. Its infernal sound has no analogues, and its magic nature has been given birth by the cosmos itself. Such an understanding is typical of the Turkic nations, and also of music specialists from the western and eastern countries. Empirically, it is confirmed by the personal experience of cosmonaut T. Musabayev: during two years of flights on the orbit he heard the melody of kobyz on several occasions.

The stage director J. Khadzhiev once again focused his attention on such phenomena as the role of a shaman in society and the meaning of kobyz music and the instrument itself. Thus, J. Khadzhiev restored the ethnic genetic, historical, and aesthetic basis of Turkic world outlook. The performance turned out to be integral and deep, with spectacular content, despite the fact that some actors' performance was superficial at times, and T. Kuraliev and K. Demesinov, who played the role of Azrail, sometimes descended to the level of communication with their partners.

The performance includes a whole complex of moral, social-psychological, philosophical, and worldview conflicts. The painful spiritual search of an individual is in the centre of the stage performance. The search is displayed as wide-scale and meaningful also because it shows the destiny of a genius, a meaningful figure, whose phenomenon is still waiting to be perceived.

In May 2002 this play was staged during the international festival of Turkiclanguage countries, Nauryz, in Kazan, where B. Seitmamytov, who played the role of Korkyt, received an award for the best male role.

The TYS continues to keep alive the traditions of the Kazakh theatre: a constant interest in folklore, historical and ethical-philosophical as well as psychological problems, attitude towards the stage language as an important instrument of spirituality (the use of monologues), devotion to the actor's psychological game, love of stage metaphor and symbols through the images of heroes, musical instruments, private possessions, weapons, etc. The political changes that are taking place in Kazakhstan, as well as the important spiritual and economic changes, require a search for new expressive means, innovation of the stage language, and a dialogue with the spectator. So, the Gabit Musrepov Kazakh Academic Theatre for Children and Youth is in constant search. 


\section{THE MEANING OF THE 'EXISTENCE PUZZLE' PERFORMANCE}

The well-known Kazakh film critic Bauyrzhan Nogerbek, who has studied the impact of folk traditions on the cinema, has defined several levels of screenfolklore relationship in a movie (Nogerbek 2010: 29). These are as follows:

The direct level - filming folkloric and literary works; the indirect interpretation level - creating films based on folkloric and literary works; the quotation level - when the understanding and inclusion of folklore fragments in the film structure take place organically, at the modern artistic thinking level. (Fomin 1983: 140)

Valeriy Fomin, when studying the ambiguous role of folklore, notes that "a folklore fragment is, in most cases, a complex and key metaphor, a kind of poetic mirror, in which the 'non-folk' part of the narrative is reflected; this part vividly reveals the hidden problems, conflicts, and new semantic values" (Yampolsky 1993: 61). The theatre situation is somewhat different. Theatrical art is the 'root bearer' of folklore traditions in the form of oral works and songs.

Kazakh folklore is full of ideas, images, and symbols, linked by epics, rituals, and games. Its means of expression include the word, music, movement, dance, plastic art, and improvisation - all that makes the theatre a modern phenomenon, with its specific staginess and originality. Comprehension of the theatrical nature through the play, folk music, and the plot is often linked with numerous signs and symbols. "The Kazakh music culture has traditions of such folk singers as 'sal' and 'seri', based upon contests of oral folklore genres and singing” (Khalykov \& Karzhaubaeva 2013: 217). Obviously, all the world theatres have similar experience; in other words, this problem is related to the world theatrical art and requires a comprehensive study, which implies a high level of generalisation. And, last but not least, the theatre has kept the original effective character of folklore plays. Every nation, in every period of its history, cultivates the art of performance, as well as acting, which corresponds to the realities and traditions of the society where it exists. It is connected with the evolution of social consciousness and with a certain set of resources (art, technology, etc.), which are inherent in a particular epoch. All researchers agree that "it is clear that the development of the theatre kept its originality and identity since ancient times, and thus the development of the theatre took place in all countries in the same ways, although in different historical periods. It had the same directions and genres: religious performances, oral-poetic tradition, folk or fair shows, performances of the so-called one-man theater" (Khalykov \& Karzhaubaeva 2013: 219). 
Folklore is a state of mind that is cultivated by people in their creative work, and has given life to people's substantial cultural development. Speaking about the social aspect of folklore as art, it can be called a living and inexhaustible source of all cultures. However, the action and the sound of folklore, which create the meaning of the game, are not the 'existence puzzle' in the postmodern sense; it is something profoundly different. Another thing is that philosophy and art are related to social, public relations, and public human existence.

Philosophy as something that is loudly expressed, visible consciousness, the theatre as the confirmation of sleepless existence and the art itself are the means of keeping and prolonging consciousness, which make the culture vivid. Without it, culture would transform into imitation, a frozen and dead collection of the monuments of culture. (Khalykov 2009)

The birth of consciousness, expressed as a performance at the theatre, just lies in the opening of this groundlessness of a human being, and the necessity to take one's own decisions. Being puzzled by existence, which stuck a human being in the very aggregate of its attentive habituation, perplexity dawned upon him with a strange light and the whole structure of his seemingly good routine life, as Anatoly Akhutin wrote, will prevail in his existence from now on (Akhutin 1997: 117). Thus, we see that game and seriousness do not exclude each other, and that the theatre, in particular, and the art, in general, do not simply evoke joyful feelings, but also provoke and suggest the Idea, which is the fundamental issue of human existence. According to Nietzsche's philosophy, "not only the limits, but the dignities of this Nietzsche's relation between philosophy and art, which are capable of searching the indescribable are beyond our abstract and scientific vision, the notion of tragic, and existential truth of life" (Nietzsche 1982: 544). The game's aesthetic and philosophical experience of the sharpened consciousness, astonishment, and amazement turned out to be in their aggregate as a single whole - spiritual search, in which the division into feelings, will, and thoughts is relative. As a philosophical text, these works of art are peculiar 'machines' of the intellect: their task, language, and internal 'arrangement' are called to 'suggest' the idea to a human being, to knock him out of the saddle of the ordinary language, cognitive and other stock-phrases, and to lead him into the awakening, gathered, sharpened, and attentive existence (Stefan-Sebastian 2013: 86).

Speaking about the idea of the 'existence puzzle' performance, we can see the question of the "Chronotope era when a person has no proper place in the world" (Borev 2002: 389). However, this is not the time and era of folklore predominance, or the era of the primeval culture. It is "the Topos Era, which implies the artistic space thinking and Man is on the stage, merging with nature: 
almost absolute dominance of nature over Man" (ibid.: 281). Nietzsche called the culture existing before the twentieth century - as Apollonia and the culture of the twenty-first century - Dionysian. Thus, the idea of the 'existence puzzle' performance is more suitable for deconstruction, absurdity, destruction, and other postmodern terms. Culture loses its human idea inherent in folklore along with sincerity, steadfastness, and constancy of being. After gaining abstract dimensions in human perception, the theatre has gotten tired of deconstruction and needs positive myths, legends, folklore heroes, and the real human art.

\section{CONCLUSION}

"The history of scenic art is always a dialectic interaction between the traditional and the new. The ratio of folklore and the new professional theatrical forms changed at different historic stages on the Kazakh scene" (Kabdieva 2002: 19). Folk traditions were still the factor that formed the Kazakh theatre. The Gabit Musrepov Kazakh Academic Theatre for Children and Youth became the place where dramatic stories of verbal folklore along with their problems, characters, and the imagery system became the basis of the Kazakh dramaturgy, and folk songs constituted a basis for the Kazakh opera and musical drama theatre, due to the unfading examples of musical folklore. This proves the fact that Kazakh folklore, which represents the content of the Kazakh national life, acquired universal significance, having assumed the noble mission of understanding and rapprochement between peoples. The traditional Kazakh Puppet Theatre Orteke (meaning 'a goat'), whose name originates from the galloping animal, playing the dombra (musical string instrument), embodies an intangible spiritual value, and it is also based on folklore. Orteke is recognized by UNESCO as a part of the world heritage, one of the spiritual values of the mankind. All kinds of arts revived by the young Kazakh artists are inspired by folklore, its symbols, and characters. The transformation of folklore is also widely used in modern popular music (Kazakh ethno-folk groups Turan, Ulytau, Roksanaki) and contemporary art (centre Red Tractor).

Globalising cultural signs show that the current state of human existence in culture reflects certain fragility, impermanence, and fragmentation. It means that the human being needs steadfastness, purity, and unselfishness. This can be derived only from art and folklore. As an important factor of cultural integration and an indispensable means of succession, traditional folk art has created and is still creating truly aesthetic and moral values. The present social and cultural situation is marked by a contradiction between the potential impact of the musical, visual, and verbal folklore heritage as a bearer of human values 
and aesthetic experience of the formation and development of social spiritual culture and the lack of a stable need of the younger generation to communicate with this type of national culture.

The problem of traditions and their interconnection with the culture of everyday life is of interest in cultural and art studies. The traditional world outlook of the Kazakhs remains the basis for the deep originality of the Kazakh theatrical, musical, and folkloric art, embodied in a complex of national ethnic and cultural traditions.

\section{REFERENCES}

Aiupov, Nurmagambed 2006. Tiurkskaia filosofiia: desiat' voprosov i otvetov. [Turkic Philosophy: Ten Issues with Answers.] Almaty: Kainar.

Aiupov, Nurmagambed 2012. Tengrianstvo kak otkrytoe mirovozzrenie. [Tengrianism as an Open World Outlook.] Monograph. Almaty: KazNPU im. Abaia. Available at http://tengrifund.ru/tengrianstvo-kak-otkrytoe-mirovozzrenie.html, last accessed on November 22, 2015.

Akhutin, Anatolii 1997. Rozhdenie soznaniia: Drevnegrecheskaia tragediia i filosofiia. [Birth of Consciousness: Ancient Greek Tragedy and Philosophy.] In: A. Akhutin (comp.) Tiazhba o bytii. Moskva: Russkoe fenomenologicheskoe obshchestvo, pp. 117-161.

Auezov, Mukhtar 2012. Kazakhskii epos i dorevoliutsionnyi fol'klor. [Kazakh Epic and the Pre-Revolutionary Folklore.] Available at http://el.kz/m/articles/view/ content-3510, last accessed on November 22, 2015.

Borev, Iurii 2002. Estetika: Uchebnik. [Aesthetics: Textbook.] Moskva: Vysshaia shkola.

Eleukenov, Sheriazdan 1987. Ot fol'klora do romana-epopei: Ideino-esteticheskoe i zhanrovoe svoeobrazie kazakhskogo romana. [From Folklore to the Epic Novel: Ideological-Aesthetic and Genre Originality of the Kazakh Novel.] Monograph. Alma-Ata: Zhazushy.

Fomin, Valerii 1983. Kino i fol'klor: stupeni vzaimodeistviia. [Film and Folklore: The Levels of Interaction.] Voprosy metodologii i metodiki izucheniia istorii sovetskogo teatra $i$ kino. [Questions of Methodology and Technique of Studying the History of Soviet Cinema and Theatre.] Kishinev: Shtiintsa, p. 75.

Heidegger, Martin 1997. Being and Time. Transl. by V. Bibikhin. Moscow: Ad Marginem.

Kabdieva, Saniia 1986. Fol'klornye traditsii v kazakhskom teatre. [Folk Traditions in the Kazakh Theatre.] Monograph. Alma-Ata: Oner.

Kabdieva, Saniia 2002. Kazakhskii teatr na kanune peremen. [The Kazakh Theatre on the Eve of Change.] In: S. Kabdieva (comp.) Sovremennoe iskusstvo Kazakhstana: problemy i poiski. [Contemporary Art of Kazakhstan: Problems and Searches.] Almaty: Fond Soros-Kazakhstan, p. 24.

Khalykov, Kabyl 2009. Bytie cheloveka v sovremennom iskustve: perfomansi i aksii. [Human Genesis in Modern Art: Performances and Acts.] Aktual'nye problemy 
gumanitarnykh i sotsial'nykh issledovanii. VII Regional'naia nauchnaia konferentsiia molodykh uchenykh Sibiri v oblasti gumanitarnykh $i$ sotsial'nykh nauk. [Topical Problems of Humanitarian and Social Study: Materials of the 7th Regional Scientific Conference in the Field of Humanitarian and Social Sciences.] Novosibirsk: Novosibirskii gosudarstvennyi universitet, pp. 176-180.

Khalykov, Kabyl \& Begalinova, Gulnara 2013. The Highest Art Tasks of the World and Humans Transforming. World Academy of Science, Engineering and Technology, Vol. 7, No. 5, pp. 558-567. Available at http://waset.org/ publications/4131/the-highest-art-tasks-of-the-world-and-humans-transforming, last accessed on November 22, 2015.

Khalykov, Kabyl \& Karzhaubaeva, Sangul 2013. Traditional Culture and Up-To-Dateness SPACE INTERACTION: Artistic and Cultural Processes in Kazakhstan. In: A. Sandu \& A. Caras (eds.) International Scientific Conference Tradition and Reform: Social Reconstruction of Europe, November 7-8. Bucharest: Medimond, pp. 217-220.

Mergaliev, Daniiar 2007. Fol'klorno-mifologicheskoe nasledie kazakhskogo naroda. [Folklore-Mythological Heritage of the Kazakh People.] Izvestie Altaiskogo gosudarstvennogo universiteta, Vol. 4, No. 3, pp. 129-131. Available at http:// cyberleninka.ru/article/n/folklorno-mifologicheskoe-nasledie-kazahskogonaroda, last accessed on November 22, 2015.

Nietzsche, Friedrich 1982. Daybreak: Thoughts on the Prejudices of Morality. Transl. by R. J. Hollingdale. Cambridge, UK: Cambridge University Press.

Nogerbek, Bauyrzhan 2010. Folklore Traditions in Kazakh Cinematography. San'at: Journal of the Academy of Arts of Uzbekistan, No. 1, pp. 58-61. Available at http://sanat.orexca.com/2010/2010-1/bauryrjan_nogerbek-2/, last accessed on November 22, 2015.

Nurpeis, Bakhyt 2010. Poiski kazakhskoi rezhissury v gody nezavisimosti. [Searches of the Kazakh Stage Direction in the Years of Independence.] Voprosy iazyka, literatury i iskusstva. Respublika Kyrgyzstan, Nos. 1-2. Bishkek: AVRASYC, pp. 262-267.

Satpaeva, Shamshiiabanu 2015. Kazakhskii fol'klor $v$ otsenke zarubezhnoi kritiki. [Kazakh Folklore in the Evaluation of Foreign Criticism.] Available at http:// bibliotekar.kz/shamshijabanu-kanyshevna-satpaeva-vejani/kazahskii-folklor-vocenke-zarubezhnoi-k.html, last accessed on November 22, 2015.

Ştefan-Sebastian, Maftei 2013. Philosophy as 'Artwork': Revisiting Nietzsche's Idea of a 'Philosophy' from the Point of View of the 'Artist'. Procedia: Social and Behavioral Sciences, Vol. 71, pp. 86-94. DOI:10.1016/j.sbspro.2013.01.012.

Yampolsky 1993 = Iampol'skii, Mikhail. Pamiat' tiresiia: intertekstual'nost' $i$ kinematograf. [Memory of Tiresius: Text Studies and Cinema.] Moskva: RIK Kul'tura. 